\title{
An integrative geological and geophysical approach to characterize a superficial deltaic aquifer in the Camargue Plain- France
}

\author{
Laura Torres-Rondon*a, Simon Damien Carrière ${ }^{\text {a }}$, Konstantinos Chalikakis ${ }^{\text {a }}$, and Vincent Valles ${ }^{\text {a }}$ \\ ${ }^{\text {a }}$ UMR 1114 EMMAH (INRA -UAPV). 33 rue Louis Pasteur, 84000 Avignon-France.
}

\begin{abstract}
Deltaic aquifers are complex due to the important heterogeneity of their structure and their hydrogeological functioning. Auger drilling provides localized but very robust geological and hydrogeological information, while geophysical surveys can provide integrated subsurface information. An effective, easy to use and low-cost methodology combining geological/hydrogeological information from augers drillings and the results from three geophysical techniques (Electromagnetic mapping, Electrical Sounding and Electrical Resistivity Tomography) is being developed to characterize the structure of typical Mediterranean deltaic aquifer. A first hypothesis about hydrodynamic properties of aquifer is also obtained. The study area is located in the Rhone delta (Middle Camargue / south of France). Integration of geophysical and geological techniques allowed identifying the presence and lateral extension of the St Ferreol paleo-channel, the vertical contact between lagoonal-fluvial deposits and the marine clayed silt which separate superficial aquifer from the deeper aquifer. Likewise, a high north-south heterogeneity and east-west homogeneity was highlighted in the study area. Presence of clay in sandy deposits in the low areas implies changes in lateral hydraulic permeability. This fact, jointed to the low hydraulic gradient, suggests a slow groundwater flow in the local system. The Rhone delta presents a typical configuration of a Mediterranean deltaic aquifer thus this methodological approach can be used for similar deltaic Mediterranean systems.
\end{abstract}

Keywords: Rhone delta, Camargue plain, augers drillings, electrical sounding, electrical resistivity tomography, Electromagnetic mapping

\section{Introduction}

Due to their depositional conditions, deltaic aquifers are characterized by many complexities (Bardach, 1989; Ezzy et al., 2006; Holman, 2006; Sherif et al., 2012; Vouillamoz et al., 2007) such as: (1) Spatial and granular heterogeneity. Granulometric contrasts of deltaic systems can be very strong. Deltaic systems also have a high lateral and vertical variability (3D variability). (2) Salinization of groundwater. The salinity can be trapped by fine-grained sediments (principally clay) and stays inside. (3) The vulnerability to anthropogenic activities, because of shallow water-table and population density. (4) Others atmospheric events, for example, warmer climate or evapotranspiration. Accordingly, research and modeling of deltaic aquifers is complicated in many cases.

In order to develop a mathematical or a conceptual model of groundwater flow of a hydrogeological system, identification of structures is essential to establish geological and hydrodynamic limits. Geological and geophysical methods have been used over the last decade to estimate the geometric characteristics and internal features of aquifers (Guerin, 2005). Nevertheless, in deltaic systems the recognition of paleo-structures and groundwater flow becomes a difficult work because of spatial variability and salinity content.

Classic geological techniques, such as core sediment analysis, allow detailed description of the texture and origin of sediments. This type of techniques is considered the most direct method for obtaining subsurface data (Goldman and Neubauer, 1994); however, sometimes, geological data is spatially limited. In contrast, geophysical measurements can provide a less expensive and effective way to fill the lack of knowledge between boreholes or auger drillings (Boucher et al., 2009; Chalikakis et al., 2009; Maillet et al., 2005; Martínez et al., 2009; Vouillamoz et al., 2007). The integration between geological and geophysical surveys allows obtaining more precise images of subsurface (Falgàs et al., 2011; Lyons et al., 2011).

Several works have used combination of geophysical techniques to characterized structure of different types of deposits (Falgàs et al., 2011; Pham et al., 2002; Sandberg et al., 2002; Skinner and Heinson, 2004). In particular, combination of Electromagnetic (EM) mapping and Electrical survey (Electrical Resistivity Tomography (ERT) and Electrical Sounding (ES)) was used to this purpose (Al-Fares, 2011; Sirhan and Hamidi, 2012). However, only ERT is the most commonly used geophysical technique to characterize deltaic sequences or mainly salinity variations (Maillet et al., 2005; Martínez et al., 2009; Zarroca et al., 2011).

The Middle plain of the Rhone delta, in the south-east of France (Fig. 1A), is a mixed environment with fluvial deposits forming elongate sand bodies with meanders pattern isolating freshwater to brackish water ponds (Boyer et al., 2005). Geological configuration of the Rhone delta is similar to others deltaic systems (Boyer et al., 2005; Falgàs et al., 2011; Iribar et al., 1997) such as: the Ebro delta, the Tordera delta, the Llobregat delta, the Tibre delta, the Nile delta and the Pô delta. A large number of geological and hydrogeological studies have been carried out to understand the dynamic behavior of deltaic aquifers of the Rhone delta (Camargue, 1970; Godin, 1990; Heurteaux, 1969; L'Homer, 1975; Marinos, 1969; Pons et al., 1979). These studies provided the first general information (large scale and low resolution geological models) and noted 


\section{Version définitive du manuscrit publiée dans / Final version of the manuscript published in : \\ Comptes Rendus Géoscience (2013), Vol. 345, Nº.5-6, p. 241-250, DOI: 10.1016/j.crte.2013.07.002 \\ Journal homepage: http://www.sciencedirect.com/science/article/pii/S1631071313001144}

the importance of the superficial aquifer of the Rhone delta. For a comprehensive hydrogeological/hydrodynamic study, a detailed and accurate structural model is needed.

The study area is located in north of the Vaccares lagoon in the Cabassole Mas (Fig. 1). This area was chosen for three reasons: (1) it is located in the central part of the Rhone delta; (2) it represents the typical geomorphology of superficial structures of the Middle Camargue plain; and (3) it intercepts functional units from the north to the south (Griolet, 1972): contact with the "Grand Mar" marsh and the Vaccares lagoon, presence of lagoonal deposits (low elevation zones) and fluvial deposits (high elevation zones). The Montlong channel flows across the study area. This channel is an ancient tributary of the Rhone River which construed the St Ferreol paleo-channel (Arnaud-Fassetta, 1998).

The aim of the study is to obtain an effective, easy to use and low cost methodological approach to characterize a superficial deltaic aquifer through the contribution of auger drillings and three geophysical methods (EM mapping, ERT and ES). The final purpose of this work is to build a structural model of this type of aquifer.

\section{Geological and Hydrogeological settings}

The Rhone delta is located in the Gulf of Lyon, south-east of France. It has an area of $1740 \mathrm{~km}^{2}$, approximately (Fig. 1A). The Grande Camargue $\left(\approx 750 \mathrm{~km}^{2}\right)$ has been formed by ancient channels of the Rhone River and offshore bars, which constitute elongated topographic highs.

The delta plain was mainly formed during the Quaternary period, by a progradation of sedimentary bodies influenced by fluvial sedimentary flows (Boyer et al., 2005; Vella et al., 2005). Bouteyre and Toni (1972) recognize two morphological units in The Grande Camargue, according to geology: (1) The fluvio-lagoonal Camargue unit (from Arles to the offshore bar in south of the Vaccarès lagoon), composed by a fluvial covering, with riverbanks deposited over lagoonal salt formations; and (2) The lagoonal-marine Camargue unit (south of the offshore bar), consisting of marine and lagoonal deposits covered by a limited fluvial layer.

The Middle Plain is a mixed environment with fluvial deposits forming elongate sand bodies (ancient riverbanks of the Rhône River) with meanders pattern isolating freshwater to brackish water ponds. Permeability of layers is generally low (Marinos, 1969) and its distribution depends on geomorphology. Riverbanks of Rhone channel present a good permeability while marsh areas are quasi-impermeable ponds where water is retained as water of imbibition. Therefore, water-table is limited by extension of silty-sandy deposits of ancient distributary of Rhone. Hydraulic head of superficial aquifer is close to ground surface.

Vertically, Camargue region is composed by two aquifers: a gravel deep aquifer and an unconsolidated superficial aquifer (composed principally of sand and clay). These aquifers are separated by a layer of silt with peat levels, which represents an impermeable level (aquitard) between both of them. The impermeable level corresponds to substratum of local superficial aquifer.
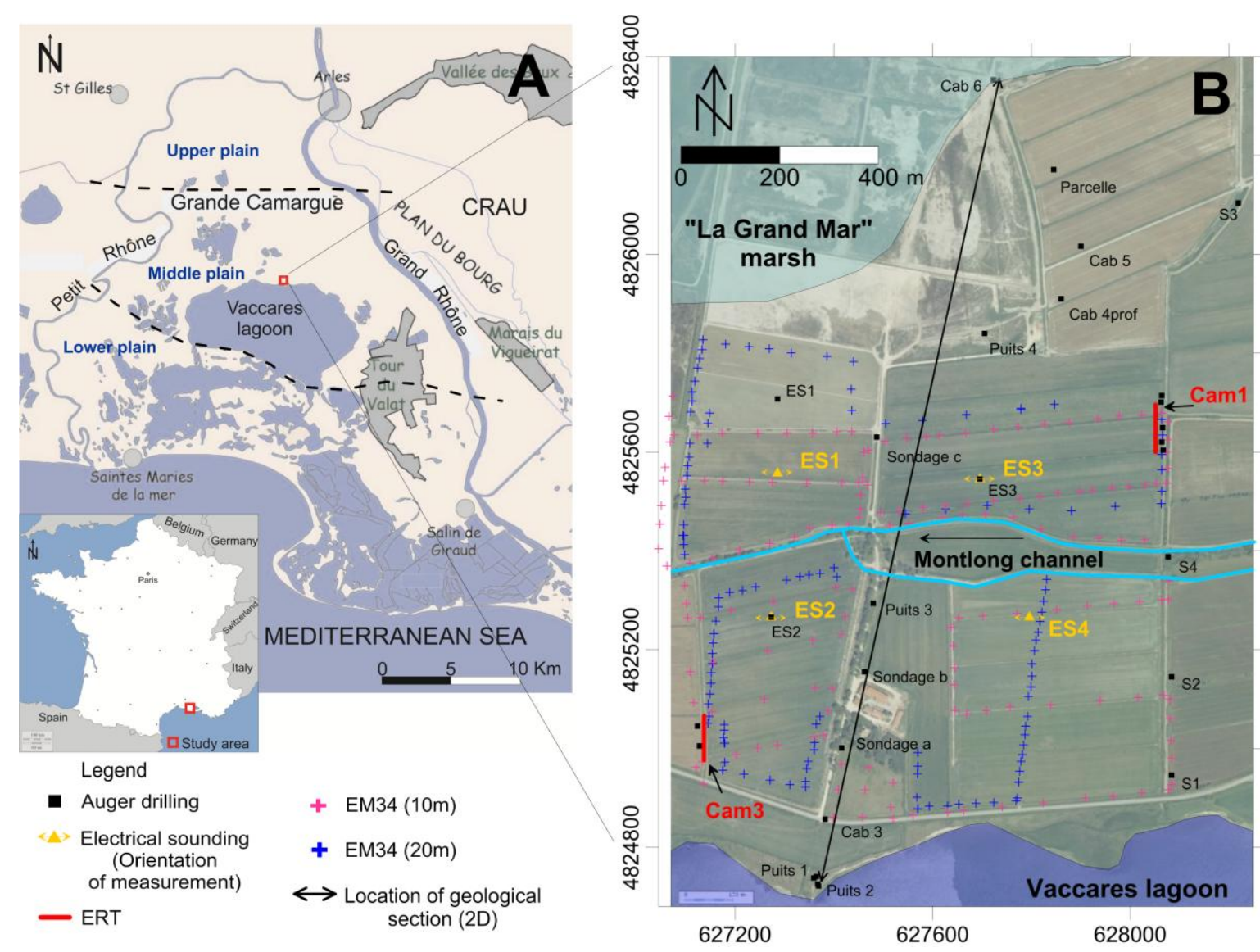

Fig. 1 A) Location of the study area, B) Cabassole Mas. Positions of: auger drillings, electrical soundings, EM34 measurement points, 2D geological section and boundary conditions 


\title{
3. Material and methods
}

\author{
3.1. Auger drillings
}

Twenty nine augers drillings were carried out between 2009 and 2012 (Fig. 1B) to provide detailed lithological description and groundwater information. A hand auger of $8 \mathrm{~m}$ length and $10 \mathrm{~cm}$ of diameter was used. Auger drillings have a depth between $3 \mathrm{~m}$ and $8 \mathrm{~m}$. This variability of the investigation depth was due mainly to the water-buried coarse grained sand deposits which made vertical extension of auger drillings impossible. Groundwater properties such as electrical conductivity (EC) and temperature were measured when was possible.

\subsection{ElectroMagnetic (EM) mapping}

The EM measurements (Slingram technique) have been used to image apparent electrical conductivity $\left(\sigma_{\mathrm{a}}\right)$ distribution in the subsurface. The basis of the Slingram technique is described in several publications (McNeill, 1980; Monteiro Santos, 2004; Parasnis, 1986; Triantafilis et al., 2003a, b; Ward and Hohmann, 1988). Despite of the qualitative nature of the provided information this technique is widely used for hydrogeological and environmental investigations (Evans et al., 2000; Nobes, 1996; Sirhan and Hamidi, 2012). Two EM campaigns have been carried out in the central part of the study area (Fig. 1B). The first campaign was made with a transmitter- receiver separation of $10 \mathrm{~m}$ in both vertical dipole (VD) and horizontal dipole (HD) configuration. The spacing between measurements was calculated in order to cover the total area. The second campaign was made with a coil separation of $20 \mathrm{~m}$. The EM 34-3 equipment by ABEM was used.

\subsection{Electrical Resistivity methods}

Electrical resistivity is one of the main properties adapted to hydrogeophysical studies (Guerin, 2005). Resistivity of rocks is affected by different factors (Matsui et al., 2000): porosity, pore fluid resistivity, water saturation, water content by volume and clay content.

\subsection{1. $\quad$ Electrical Sounding (ES)}

ES is generally used to determine vertical variations of the electrical resistivity in hydrogeological investigations (Al-Fares, 2011; Vouillamoz et al., 2007). Four soundings were implemented in the central area of the site (Fig. 1B), close to the Montlong channel (named: ES1, ES2, ES3 and ES4), and according to the EM survey results. The Shlumberger array was used with a maximum spacing of current electrodes of $300 \mathrm{~m}$. The equipment "Geo-Instruments" developed by CNRSGarchy (France) was used. Inversion of the apparent resistivity $\left(\rho_{\mathrm{a}}\right)$ values in to geo-electrical models was made with IPI2Win 3.0.1 ${ }^{\mathrm{e}}$ version software.

\subsubsection{Electrical Resistivity Tomography (ERT)}

ERT is the most common method applied in the earth sciences especially in hydrogeology due to his robustness and reliability (Al-Fares, 2011; Chalikakis, 2006; Pham et al., 2002). Two ERT sections were carried out in the study area (Fig. 1B), the first (Cam1) is located towards the north-east zone and the other (Cam3) is located towards the south-west zone. Each section was $126 \mathrm{~m}$ long, using 64 electrodes and $2 \mathrm{~m}$ inter-electrodes spacing. Two arrays were implemented: WennerSchlumberger (WS) and Dipole-Dipole (DD); WS array provides a good compromise between horizontal and vertical resolution and DD array has a greater investigation depth (Seaton and Burbey, 2002). For the ERT acquisition the ABEM Terrameter SAS 4000 was used (Dahlin, 2001). Apparent resistivity was interpreted with Res2Dinv software, 3.59.1154.44 version, using Robust Constraint. Iteration process was limited at three iterations because that was enough to provide a satisfactory Root Mean Square (RMS) error. Only WS array is presented in this paper to simplify discussions.

\section{Results and discussions}

\subsection{Local lithology}

The subsurface in the study area is constituted only by sediments. In general, their minimum thickness is around 1 $\mathrm{m}$ and they have a large lateral extension (200-300 m). Fossils in the study area suggest a lagoonal, pond or alluvial origin. Five types of sediments have been identified. Lithological description was made using the facies described by G.E.P.P.A. triangle (Baize and Jabiol, 1995). The sedimentary environment has been determined in some cases using fossils and comparison with geological section of superficial formations ("ligne 18" Mas de Cabassole) of the Camargue report (Camargue, 1970). The sedimentary sequence, in the textural order, consists of:

1. Al-La: Silty clay, grey-yellow, to clayed silt, pale gray. Stain of iron oxide and vegetable remains are presents. Peat layers and soil horizons can be observed into this facies, giving a black color to sediment. This facies has, generally, 1-3 m of thickness. The presence of preserved fossils of gastropod type, like Planorbis and Radix limosa Linne, suggest a euryhaline and eurythermal lagoon as environmental origin. Brackish environment with freshwater contributions. This facies has been recognized in almost all observation points.

2. La: Clayed silt, dark grey. Observed in the base of Cab3 log (-6 m.a.s.l). A thin layer of marine shell remains (not differentiable) rests in the top of this facies.

3. Ls: Sandy silt, brown in the first centimeters, and then it becomes grey. Its thickness varies between $0.5 \mathrm{~m}$ and $1.5 \mathrm{~m}$. Fossil species are associated to continental-terrestrial and freshwater origin. It is sandier to the central part of the study area. Sandy silt facies is interpreted as overflow phase of the actual Montlong channel. 
4. SI-S: Silty sand (SI) and fine grained sand (S), pale grey. Identified in the lateral parts of the study area. Presence of micas (muscovite). Its thickness could not be recognized in most of cases. Sand is generally well sorted. Three types of this facies were recognized. In the south of the experimental site, fine $\mathbf{S}$ facies is identifying under Al-La facies. It presents remains of lagoonal fauna. To the north, a layer of $\mathbf{S l}$ facies is recognizing. This facies contains non differentiable fossils and clay balls of 1 to $2 \mathrm{~mm}$ of diameters. Clay balls represent an abrupt aggradation episode according to description of Camargue (1970). Both of uits proceed of lagoonal environment.

Also, in the north of the area, lens of well sorted azoic fine grained sand is present in Cab5 and Parcelle (Fig. 2). This facies could be associated to eolian environment.

5. SS: Coarse and median grained sand, grey, well sorted, micas (muscovite), sedimentary rocks remains and not differentiable fossils remains are abundant. Flat remains of wood, of 3-7 cm, have been observed into the sediments. This facies was interpreted as filling of a fluvial channel, cuts the facies above. It has been identified in the central part of the study area (close to Montlong channel) as well as in the base of Cab6 and Cab7 logs, accompanied by pebbles. These deposits have an abrupt contact with the rest of sediments.

A north-south reconstruction of the geometry of the deposits in the middle of the study area was attempted through the lithological description presented above (Fig. 2). Stratigraphic correlation is based in textural characteristics and horizontality of layers. Bouteyre and Toni (1972) present the Middle Camargue as composed by a fluvial overlay with large riverbanks covering previous salty lagoonal formations. According to textural characteristics and fossils recognized, five types of sedimentary environment can be identified: Marine (M), Deposits of saltwater marsh (L), Eolian (D), Fluvial (F) and Paludal (P). This sedimentary sequence is progradational corresponding to description of Boyer et al (2005). In the same environmental sequence, vertical contact between facies is not clear, due, probably, to changes of energy. This happens principally with deposits of lagoonal origin. However, the contact between stratums of different depositional environments is net. Fluvial deposits identified in the central part of the study area (close to Montlong channel) correspond to the St Ferreol paleo-channel. According to description of the auger drillings width of paleo channel varies between 300 and $500 \mathrm{~m}$, approximately.

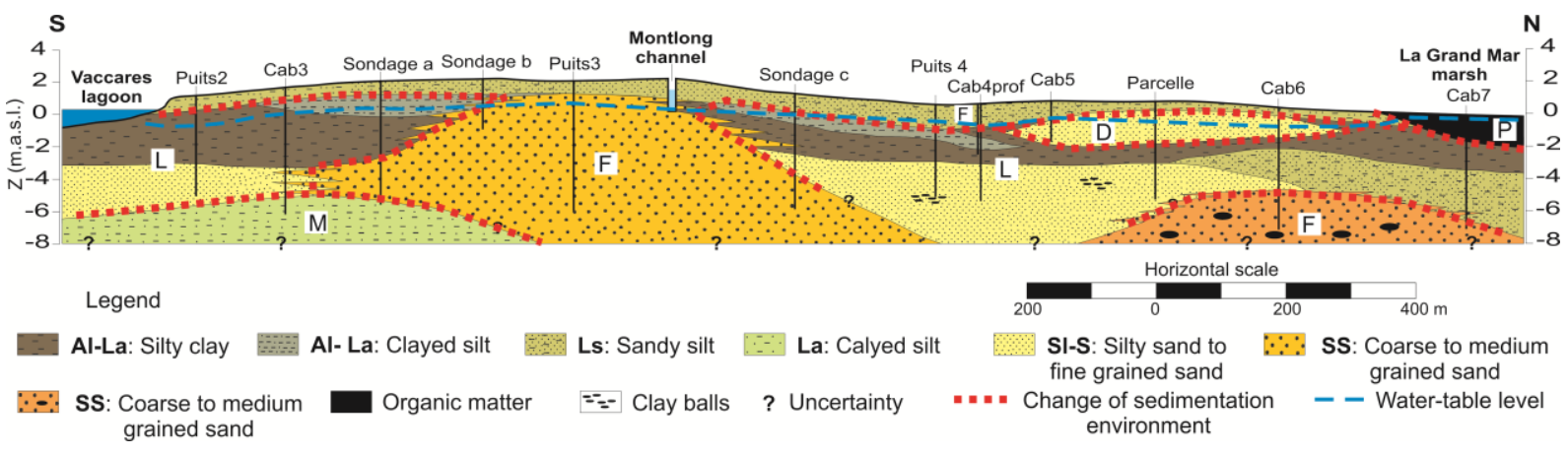

Fig. 2 A north-south geological section with position of the auger drillings and their related investigation depth. According to the lithological description sedimentary environment are recognized: F- Fluvial, L- Deposits of saltwater marsh, D- Eolian, P- Paludal and M- Marine (See Fig. 1B for location)

\subsubsection{Local hydrogeology}

Two groundwater tables were recognized within the same superficial aquifer during auger drillings implementation: a fine perched groundwater table in the first meters below the surface (limit between Ls facies and Al-La facies). The second appears in the sandy facies (Sl-S and SS). The aquifer presents two hydrogeological behaviors: unconfined behavior in the higher topographic areas (close to Montlong channel) and confined behavior in the lower parts where Al-Sa facies is present. In general, the aquifer follows local topography, therefore water table is quasi-horizontal and its hydraulic gradient is low.

The mean EC of the aquifer for three observation points located within the experimental site (cf. Fig1B) is exposed in Table 2. EC measurements were carried out every month between January and November 2011. These variations depend on both geomorphology and season. For instance, Puits3 point is located at the highest topographic of the site are. It is important to remind that the topography of the site is varying around $2 \mathrm{~m}$. Moreover, seasonally, EC of groundwater present the higher values at the beginning of the irrigation period (March-April). Lowest values are measured after the end of the irrigation period (September). In the period before and just after irrigation (from October to February), EC values are stable.

Table 1 Groundwater EC variation (mean values over eleven months) in three observation points

\begin{tabular}{ccc}
\hline & \multicolumn{2}{c}{ Conductivity $(\mathbf{m S} / \mathbf{c m})$} \\
Obs. points & Summer & Winter \\
\hline Cab3 & 1.6 & 1.4 \\
Puits3 & 0.8 & 0.7 \\
Cab4prof & 12 & 2 \\
\hline
\end{tabular}


In general, seasonal variation of EC is low in the elevated parts (Puits3 and Cab3) but is very high in the lowest area (Cab4prof). Irrigation decreases EC values of the near surface aquifer. Low groundwater flow conducts groundwater from highest areas to the lowest areas. In the lowest parts, outflow is caused by evapotranspiration. So, the highest values of EC during March and April are probably due to evapotranspiration and salt accumulated into the sediments. Based in this result all geophysical measurements have been made in the period before and just after irrigation (from October to February).

\subsection{Geophysical results}

Local lithology section allowed observing an important lithological variability in the north-south direction. However, there was any information concerning the east-west direction also as the vertical limit of the aquifer. The sediments described previously are electrically conductive considering the expected theoretical values (Marescot, 2006). For that reason, when the term resistive or conductive is used in this paper, is referred to the relative resistivity within the values acquired on this site.

\subsubsection{ElectroMagnetic mapping}

In the first geophysical campaign, EM34 mapping was carried out in the central part of the study area in order to overview the spatial variability of the near surface features (cf. Fig. 1B). A separation coil of $10 \mathrm{~m}$ was used for this campaign (VD-10 m). The EM34 mapping provided integrative information about $\sigma_{\mathrm{a}} \cdot \sigma_{\mathrm{a}}$ values has been analyzed using geostatistical methods to calculate both east-west and north-south directional variograms and correlograms (Fig. 3).

Correlograms behavior is different in these two directions (Fig 3A). The east-west correlogram presents a linear behavior and the correlation coefficient reaches the lag distance (a1) around $680 \mathrm{~m}$; that indicate a strong correlation for two points separate by several hundred meters $(600 \mathrm{~m}$ approx) along east-west direction. A spatial continuity in east-west direction is highlighted. In the east-west (Fig. 3B) the variance is not really attained.

Contrary to the east-west direction, the north-south correlogram (Fig. 3A) get the "zero" value before a short distance (a2=160 $\mathrm{m}$ approximately). In accordance with to the north-south correlogram, the north-south directional variogram (Fig. 3B) shows also a weaker lag distance and an anticorrelation for the great distances. It highlights a higher spatial variability of the subsurface structures in the north-south direction. The difference in the correlograms and variograms behavior to both directions and value of coefficient $\mathrm{q}(\mathrm{q}=\mathrm{a} 1 / \mathrm{a} 2)>4$, exposes the anisotropy in the study area.
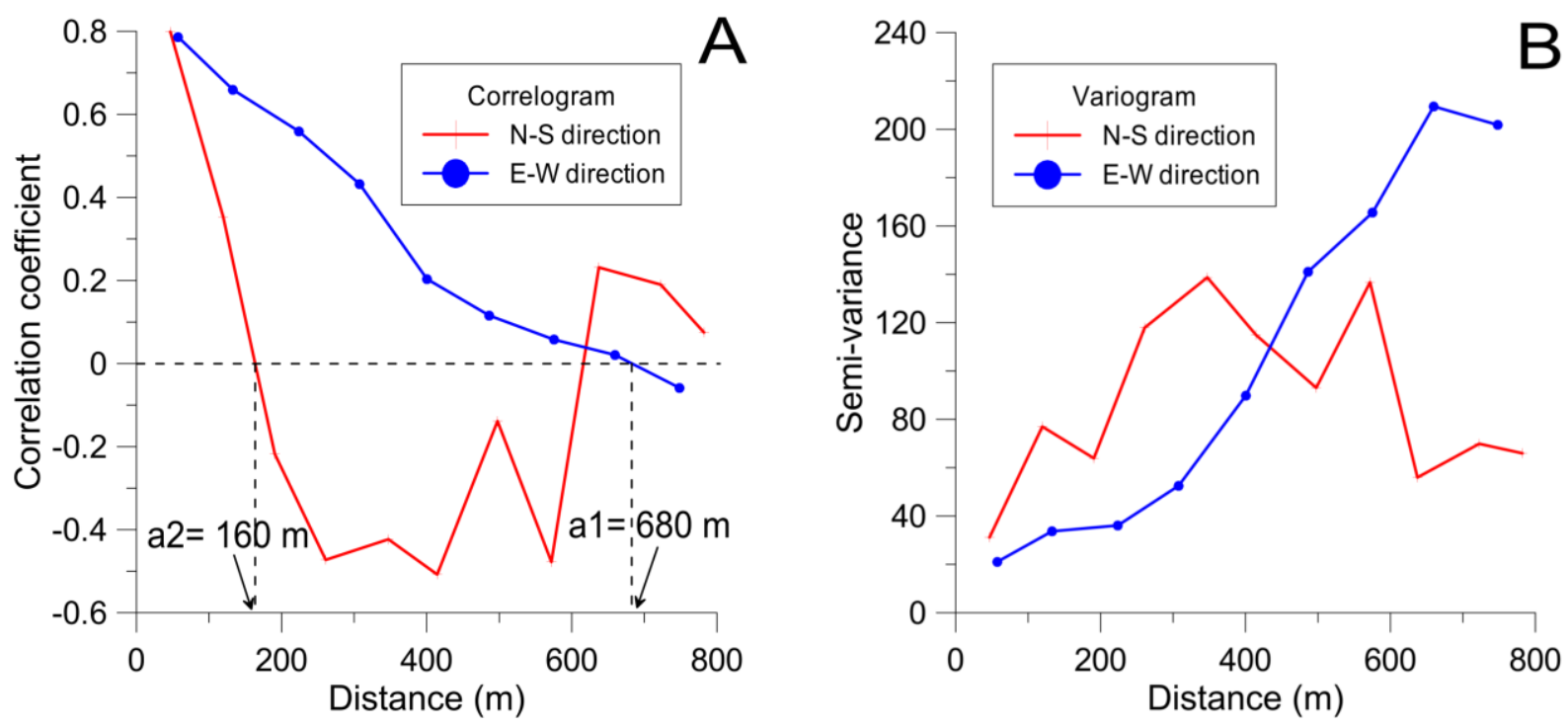

Fig.3. A) Directional variograms and B) Correlograms (values from EM mapping, VD-10 m) for both east-west and northsouth directions.

The geostatistical results served as a base to the second EM campaign that was carried out with a larger investigation depth $(20 \mathrm{~m})$. Due to the observed spatial anisotropy of the subsurface features of the study area, it was considered to densify the measurements in the north-south direction while the measurements in east-west direction were more distant (cf. Fig. 1B).

Both EM maps (VD-10 m and VD-20 m) show a spatial heterogeneity in the north-south direction (Fig. 4), while, in the east-west direction an oriented structure was highlighted. Subsurface becomes more electrically conductive in the VD$20 \mathrm{~m}$ map. The resistive central structure of each map can be joined and a structure in form of ditch or drain is obtained (Fig.4). This structure is similar to the form of a river bed and it has a width between 200 and $400 \mathrm{~m}$ approximately. This kind of structure in the central part of the study area agrees with the existence of the St Ferreol paleo-channel described in several publications (e.g. (Arnaud-Fassetta, 1998; Camargue, 1970; L'Homer et al., 1981). 
Version définitive du manuscrit publiée dans / Final version of the manuscript published in :

Comptes Rendus Géoscience (2013), Vol. 345, N.5-6, p. 241-250, DOI: 10.1016/j.crte.2013.07.002

Journal homepage: http://www.sciencedirect.com/science/article/pii/S1631071313001144

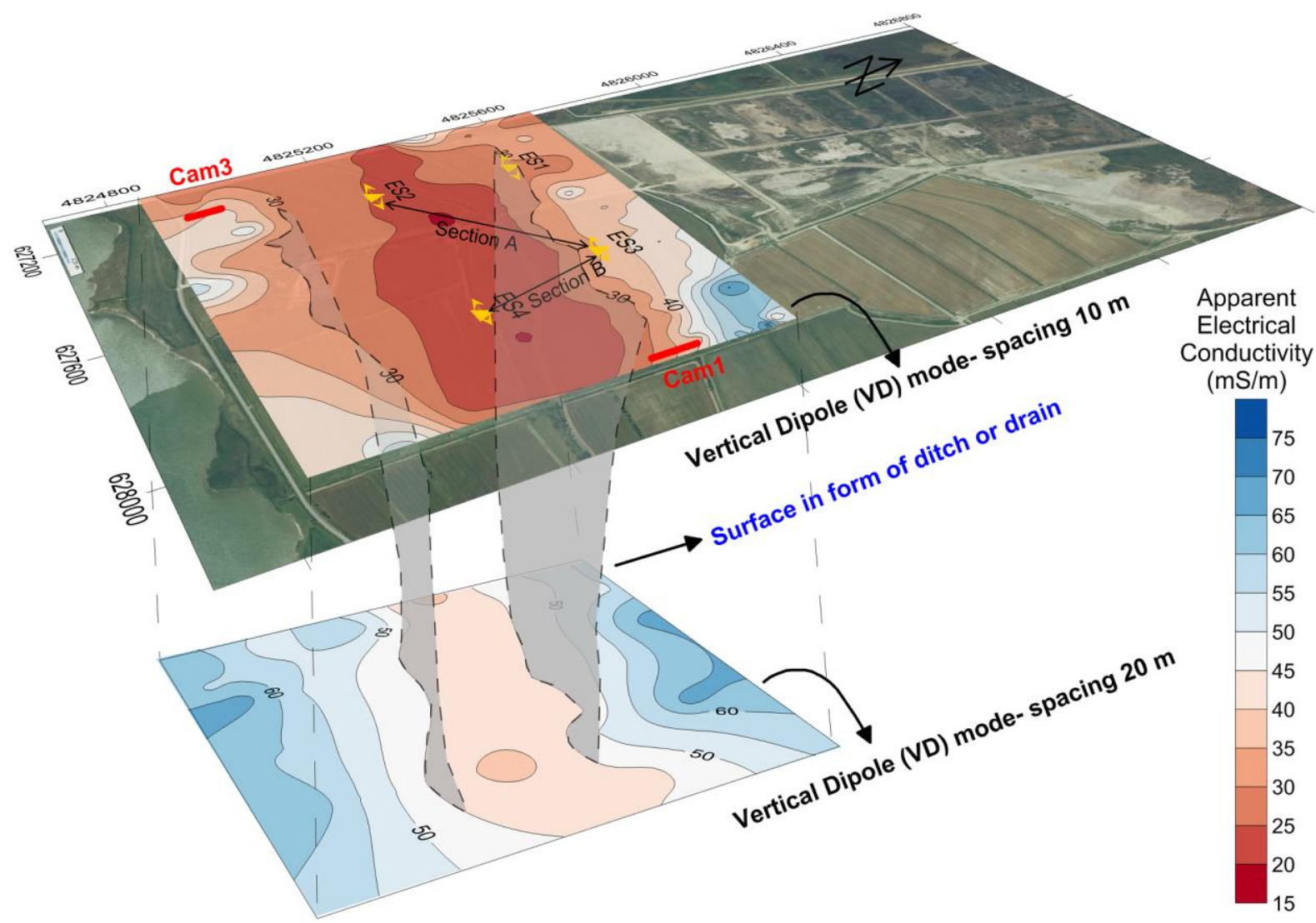

Location of ES and the orientation of measurement

Location of ERT

Fig. 4 Overlap of EM maps regarding coils spacing (Map VD-10 $\mathrm{m}$ above and Map VD-20 m below). Location of the ERT, the ES and 2D section from ES correlation

\subsubsection{Electrical Sounding}

EM34 mapping highlighted the presence of the St. Ferreol paleo-channel. However, this technique does not allow obtaining the lower limit of the aquifer; the contact with the marine silty formation (Boyer et al., 2005). Considering EM34 results and structures orientation, the ES were deployed and concentrated in the central area (Fig. 4). EC of groundwater in the central area is $700 \mu \mathrm{S} / \mathrm{cm}$ and the general depth of water table is $1.5 \mathrm{~m}$ from surface. Four auger drillings were implemented close to ES. The lithological logs were used to calibrate and constraint the inversion and interpretation of the first meters $(3-7 \mathrm{~m})$. Water table level was also taken into account during inversion. In general, apparent resistivity $\left(\rho_{\mathrm{a}}\right)$ of the interpreted layers is very low, compared to the typical obtained values (e.g. sandy formations) and this is due probably to the water presence. In addition, this range of $\rho_{\mathrm{a}}$ values was observed in others studies carried out in the Camargue plain (Cary, 2005; Maillet et al., 2005). For each lithological unit identified by the auger drillings a $\rho_{\mathrm{a}}$ value was determined by the ES results. The $\rho_{\mathrm{a}}$ values of these lithological units are presents in table 2 . For the clayed silt facies (La) its $\rho_{\mathrm{a}}$ is not directly associated lack of access through auger drilling.

Table 2 Apparent resistivity of facies and water in content in the study area

\begin{tabular}{|c|c|c|c|}
\hline Facies & Sediment & 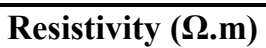 & Water content \\
\hline Al-La & Silty clay to Clayed silt & $16-20$ & yes \\
\hline Ls & Sandy silt & $31-35$ & no \\
\hline Sl-S & Silty sand to Fine grained sand & $20-30$ & yes \\
\hline SS & Coarse grained sand & $30-43$ & yes \\
\hline
\end{tabular}

Taking into account $\rho_{\mathrm{a}}$ values of local sedimentary facies, a geological interpretation of all electrical soundings is possible (Fig. 5). Attribution of $\rho_{\mathrm{a}}$ of facies allows identifying an important thickness of the SS facies. In the same way, a very conductive layer $(4-10 \Omega . \mathrm{m})$ has been identified at the base of all ES. With this range of values this layer can be 
Version définitive du manuscrit publiée dans / Final version of the manuscript published in :

Comptes Rendus Géoscience (2013), Vol. 345, N.5-6, p. 241-250, DOl: 10.1016/j.crte.2013.07.002

Journal homepage: http://www.sciencedirect.com/science/article/pii/S1631071313001144

associated to the presence of clayed silt of marine origin (La), considered in this paper as the substratum of the aquifer. A particular characteristic of the La facies is its depth variation; between $10 \mathrm{~m}$ (ES3) and $22.5 \mathrm{~m}$ (ES1). In ES2 and ES4 soundings the top of this facies is present at $17 \mathrm{~m}$ depth.

A reconstruction of the structure of the aquifer, based in ES is showed in Fig. 6. The reconstruction was carried out through two 2D sections: section A and section B (cf. Fig. 4). Section A includes ES2, ES1 and ES3, and is oriented from south-west to north-east. Section B includes ES4 and ES3, and is oriented from south to north. Structural correlation showed in Fig. 6 allowed reconstruction of the St Ferreol paleo-channel structure and its connection with adjacent facies. Comparison between two sections highlights a slope of paleo-channel from ES4 (south-east on the site) to ES1 (north-west on the site) agreeing with the paleo-flow direction (Arnaud-Fassetta, 1998).

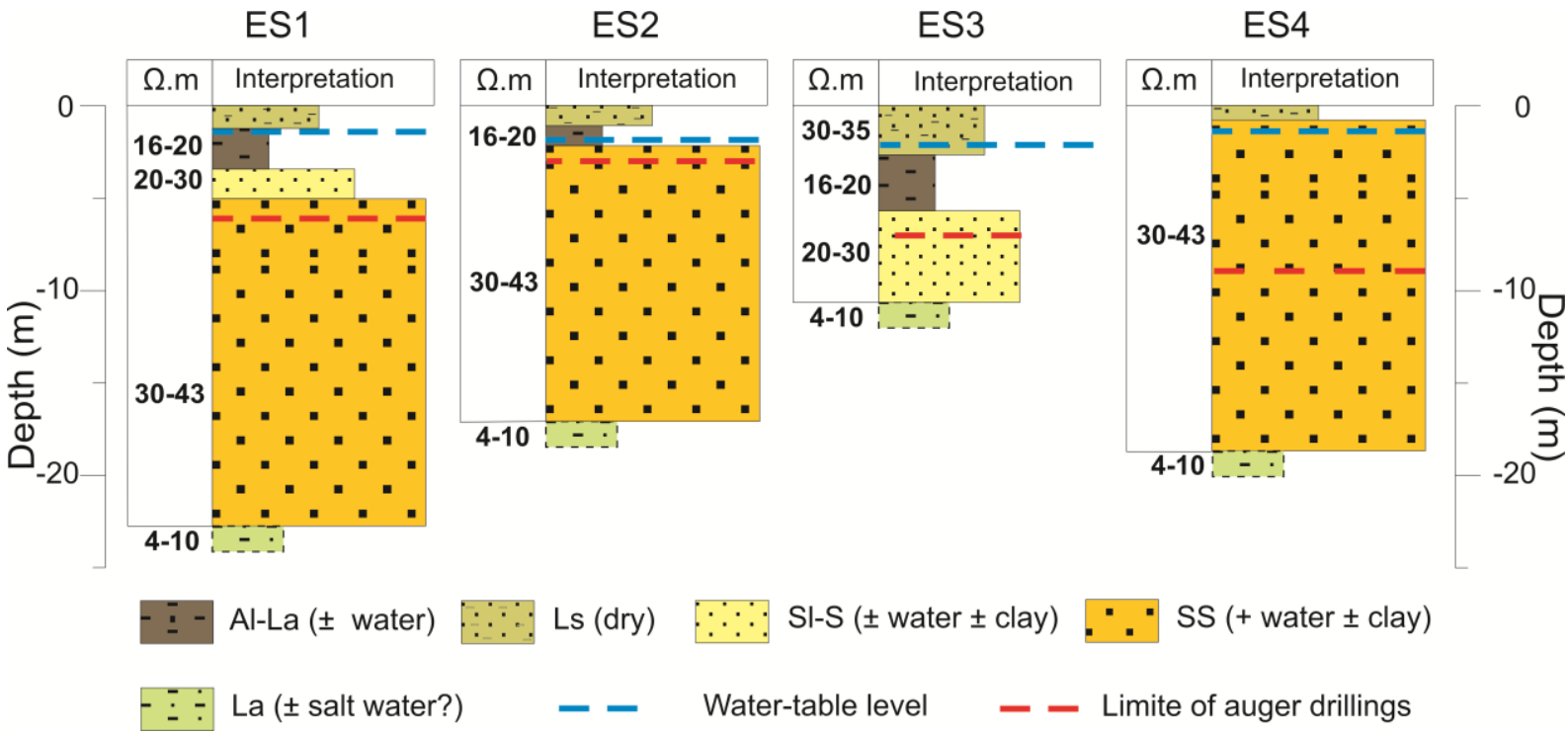

Fig. 5 Integration of the ES and the auger drillings results

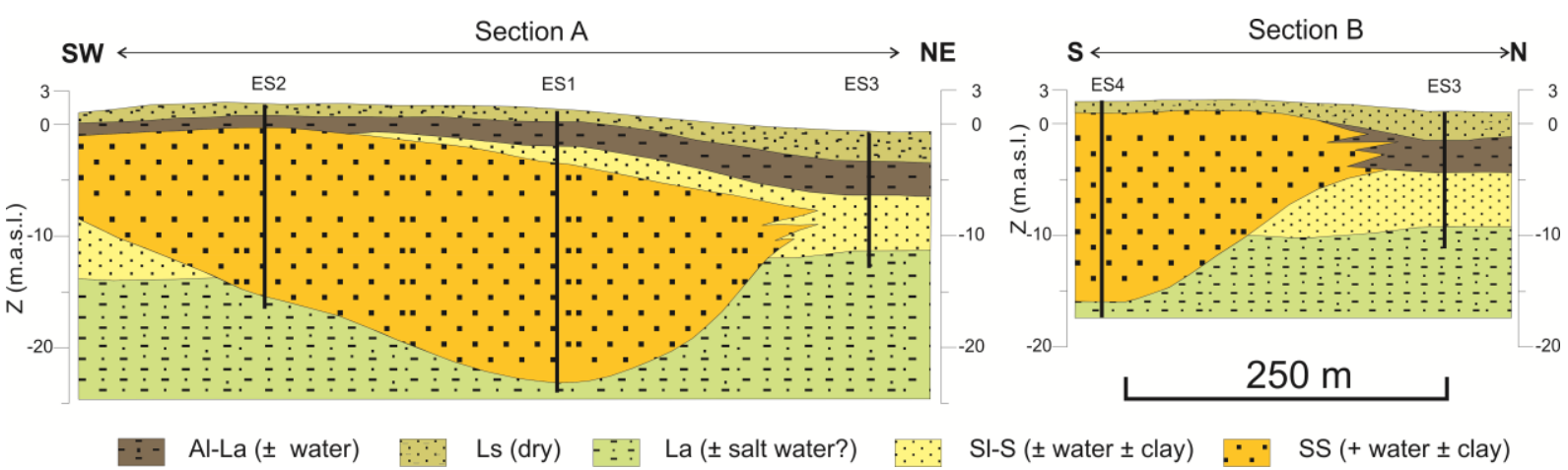

Fig. 6 Structural correlation based in ES results

\subsubsection{Electrical Resistivity Tomography}

ERT was used to determine heterogeneity degree of the central riverbank. ERT survey was implemented in zones where EM34 survey showed a strong lateral variation of $\sigma_{\mathrm{a}}$ (see location in Fig. 4). ERT section were named Cam1 (northeastern part of the site) and Cam3 (south-western part of the site). Electrodes have been oriented in north-south direction throughout the zone where EC gradient is important. Several auger drillings, between $2 \mathrm{~m}$ and $5 \mathrm{~m}$ depth, have been carried out along the ERT sections. Lithological interpretation was combined with ERT results to obtain a geological interpretation of the subsurface (Fig. 7). 
Version définitive du manuscrit publiée dans / Final version of the manuscript published in :

Comptes Rendus Géoscience (2013), Vol. 345, №.5-6, p. 241-250, DOI: 10.1016/j.crte.2013.07.002

Journal homepage: http://www.sciencedirect.com/science/article/pii/S1631071313001144
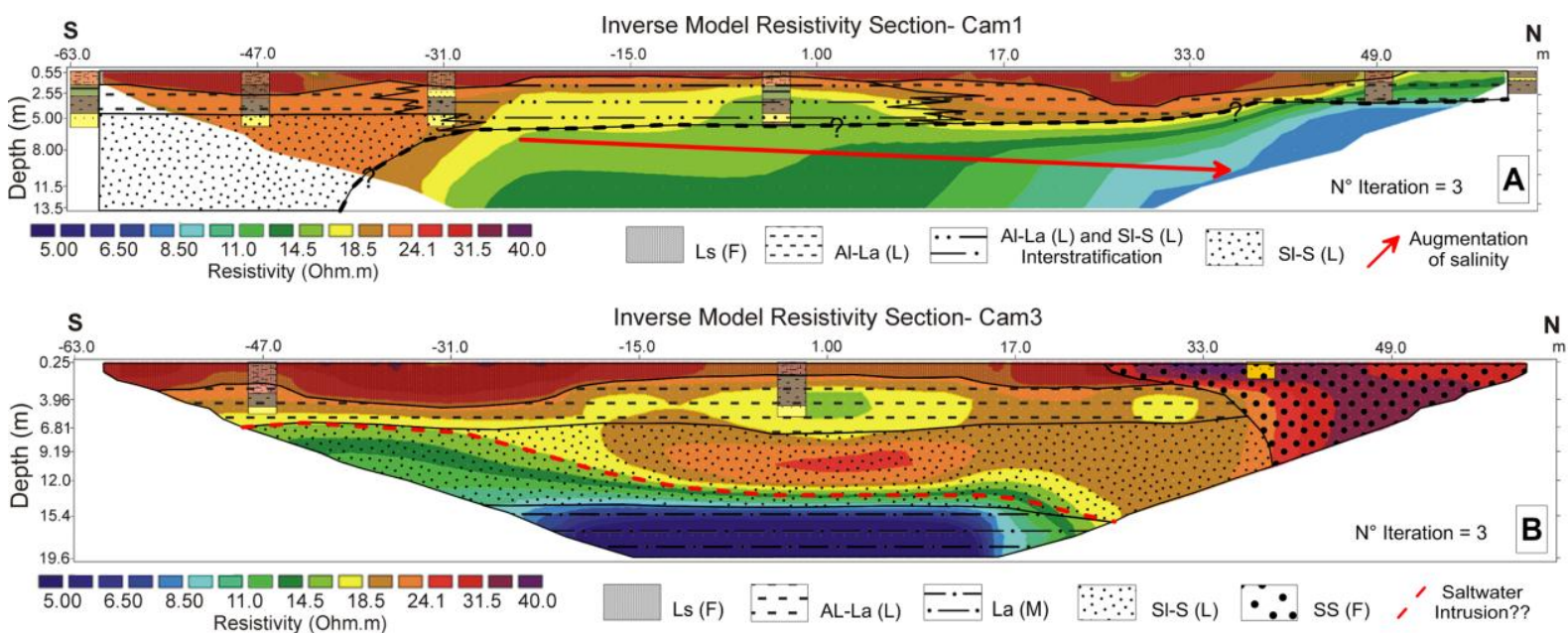

Fig. 7 Interpretation of ERT sections and superposition of the lithological correlation from the auger drillings; A) Cam1 section (iteration 3, error $=1.4 \%$ ) and $\mathrm{B}$ ) $\mathrm{Cam} 3$ section (iteration 3, error 6\%)

The obtained resistivity values vary from 5 to $40 \Omega . \mathrm{m}$. Lithological interpretation coupled to resistivity values in ERT sections were crosschecked with the $\rho_{\mathrm{a}}$ values obtained for each facies in ES results. In general, resistivity values from ERT are a bit lower than ES values, probably, due to the inversion processes.

Cam1 section presents a good correlation with lithological interpretation until $5 \mathrm{~m}$ depth (Fig. 6A). In the southern part of this section the resistive part $(\approx 24 \Omega . \mathrm{m}$ in orange) can be interpreted as a part of paleo-riverbank (St Ferreol). Superjacent layer can be interpreted as a lateral variation between clay and silty sand formations. Resistivity of the recognized layers decreases progressively in depth and northward (red arrow). Auger drillings highlight an increase of clay content also as the salinity toward to the north. In this area, EC of groundwater is multiplied by six in summer season because of evapotranspiration. The strong seasonal variations of EC of groundwater to the lowest fields in northern part of the study area suggest an impact from evaporation phenomenon. This hypothesis coupled with the fact of low lateral groundwater flow can explain the particular distribution of resistivity in the Cam1 electrical section. Accumulation of salt can be the cause of this distribution.

An even better correlation between lithological interpretation and ERT results is revealed in Cam3 section (Fig. 6B). The layers recognized in the northern part of section were identified as a limit of the St Ferreol paleo-channel (SS facies). Moreover, conductive layer in the base of the section $(\approx 5 \Omega . \mathrm{m})$ is interpreted as La facies, likewise ES results. While Ls facies were recognized near the surface, Al-La and SI-S facies cannot be easily separated within the ERT section. Cam3 section presents also a progressive passage of resistivity (dotted line) between sandy (SI-S) and silty (La) layers. This passage is thicker in the southern part of the section and it becomes more abrupt to the north. Its form is probably due to a salt water intrusion that can be compared with freshwater/saltwater transition zones described in several publications (Cooper et al., 1964; Custodio, 2002). Cam3 section is close to the Vaccares lagoon where EC of its water is $\approx 25 \mathrm{mS} / \mathrm{cm}$. All this suggest a possible saltwater intrusion from Vaccares lagoon through Al-La and Sl-S facies in the first part of section. However, this hypothesis does not reject a paleo-salinity in the silty layer due to its marine origin.

\section{Integrated interpretation}

To summarize geological and geophysical results acquired in this study, a conceptual sedimentary model of the geological system is suggested in Fig. 8. EM mapping allowed identifying the presence of a central structure probably linked to the St Ferreol paleo-channel. Geostatistical analysis of these results highlighted a lateral continuity of the subsurface structures in the east-west direction and a clear heterogeneity in the north-south direction. Therefore, characteristics of lithological units (cf. Fig. 2) could be extrapolated to east and west direction within the study area. The ES survey allows identifying the substratum of the superficial aquifer. ERT detected a series of horizontal bodies, associated to their depositional environment.

All geophysical data has been collected after the irrigation period, when EC of groundwater was stable. Thus, EC variations of subsurface are mostly linked to clay and/or water content lateral and vertical variability. Structural anisotropy of layers is evident. This anisotropy affects directly their permeability and, consequently, the groundwater behavior.

The conceptual sedimentary model includes all recognized spatial variability of the near surface features and it will be used for the development of a mathematical hydrodynamic model of the aquifer. 

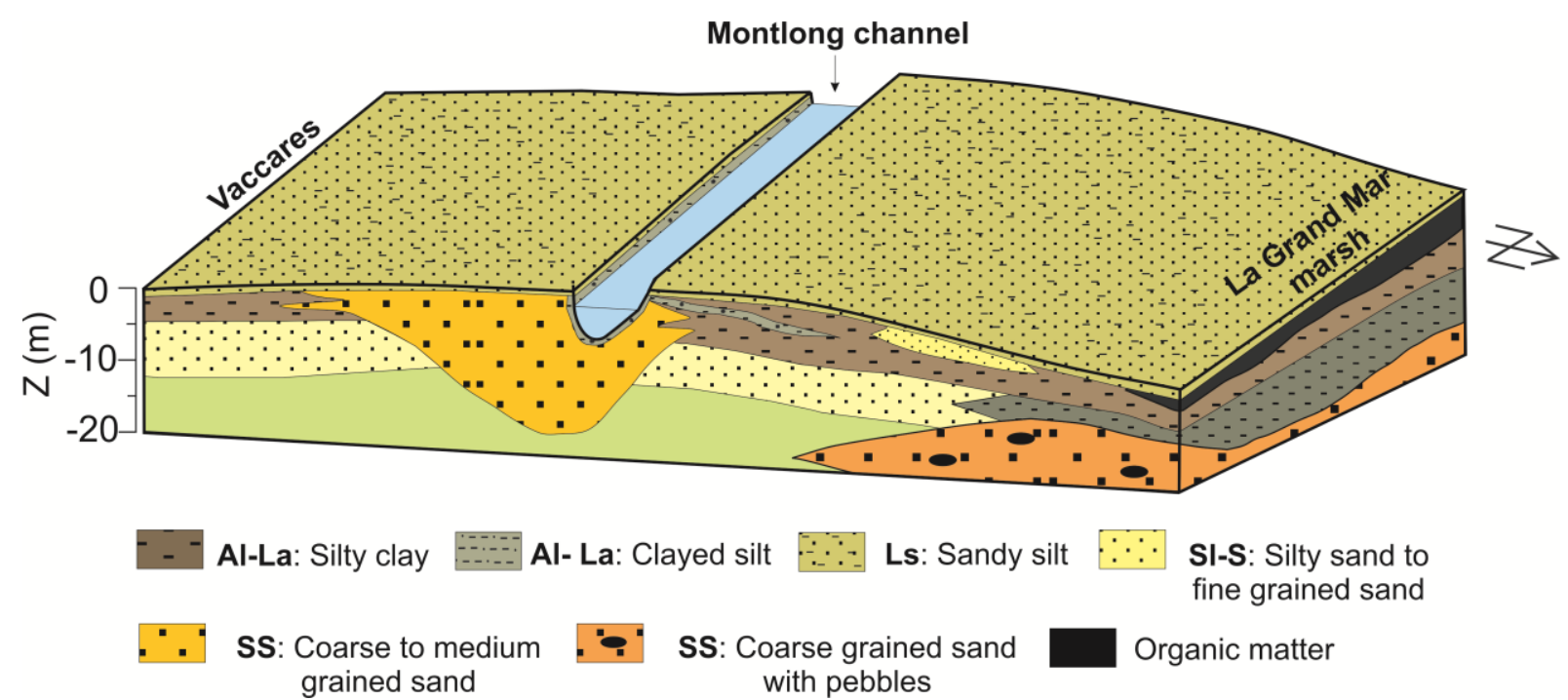

Fig. 8 Conceptual 3D model of the geometry of superficial aquifer

6.

\section{Conclusions}

Characterization of hydrodynamic behavior of aquifers depends on a good definition of boundary conditions and heterogeneity degree. Lithological characterization of aquifer's functional units allows understanding hydrogeological conditions. In fact, heterogeneity degree of functional units plays a fundamental role in groundwater flow path.

Integration of geophysical and geological techniques allowed identifying the presence and lateral extension of the St Ferreol paleo-channel, the vertical contact between lagoonal-fluvial deposits and the marine clayed silt which separate superficial aquifer from the deeper aquifer. Likewise, high north-south heterogeneity and east-west homogeneity was highlighted in the study area. Presence of clay in sandy deposits in the low areas implies changes in lateral permeability. This fact, jointed to the low hydraulic gradient, suggests a slow groundwater flow in the local system.

In this type of environment the irrigation can bring variations in the groundwater's EC. These variations can affect interpretation of geophysical results. A well suited period for geophysical techniques implementation is when EC groundwater values are stable and not influenced by anthropic activities. Certainly all measurements need to carry out within the same hydrological period or during periods presenting similar EC groundwater values.

In summary, a effective, easy to use and low-cost methodology combining geological/hydrogeological information from augers drillings and the results from three geophysical techniques (Electromagnetic mapping, Electrical Sounding and Electrical Resistivity Tomography) have being developed to characterize the structure of typical Mediterranean deltaic aquifer. The methodological approach can be summarized in: (1) Carry out a few recognition campaigns through EM mapping (several investigation depths) to identify general structuring. (2) Based on the EM results, local information can be acquired by auger drilling and ES in order to identify geological units and precise their electrical resistivity properties. (3) ERT surveys are necessary to obtain more accurate information in zones where strong lateral variations of electrical conductivity are identified. Knowledge of water table level and its EC properties are important for final interpretation. This approach can be used to study other superficial deltaic aquifers in the Mediterranean.

Acknowledgment We thank M. Philippe BRISSOT (the Cabassole Mas owner) for allowing us to use his property to conduct these surveys. We also thank O. Bour and E. Carrillo for their review and very useful comments that help us improving this paper.

\section{References}

Al-Fares, W., 2011. Contribution of the geophysical methods in characterizing the water leakage in Afamia B dam, Syria. Journal of Applied Geophysics 75, 464-471.

Arnaud-Fassetta, G., 1998. Dynamiques fluviales holocènes dans le delta du Rhône. Thèse, Université d'Aix-Marseille I, p. 329 pp.

Baize, D., Jabiol, B., 1995. Guide pour la description des sols. Inra Editions.

Bardach, J.E., 1989. Global warming and the coastal zone. Climatic Change 15, 117-150.

Boucher, M., Favreau, G., Descloitres, M., Vouillamoz, J.M., Massuel, S., Nazoumou, Y., Cappelaere, B., Legchenko, A., 2009. Contribution of geophysical surveys to groundwater modelling of a porous aquifer in semiarid Niger: An overview. Comptes Rendus Geoscience 341, 800-809.

Bouteyre, G., Toni, C., 1972. Geomorphologie et étude des sols sodiques des plaines alluviales: Exemple de la Camargue. Sciences des sols 2,32 .

Boyer, J., Duvail, C., Le Strat, P., Gensous, B., Tesson, M., 2005. High resolution stratigraphy and evolution of the Rhône delta plain during Postglacial time, from subsurface drilling data bank. Marine Geology 222-223, 267-298.

Camargue, C., 1970. Etude hydrogéologique, pédologique et de salinité. Compagnie nationale d'aménagement de la région du Bas-Rhône et du Languedoc. Rapport en quatre volumes.

Cary, L., 2005. Mobilité des éléments selon les alternances aérobie-anaérobie dans un écosystème rizicole en Camargue. Thèse. Université de droit, d'économie et des sciences-Aix-Marseille III. 
Chalikakis, K., 2006. Application de méthodes géophysiques pour la reconnaissance et la protection de ressources en eau dans les milieux karstiques. Thèse, Université Pierre et Marie Curie-Paris VI, p. 217 pp.

Chalikakis, K., Nielsen, M.R., Legchenko, A., Hagensen, T.F., 2009. Investigation of sedimentary aquifers in Denmark using the magnetic resonance sounding method (MRS). Comptes Rendus Geoscience 341, 918-927.

Cooper, H.H., Kohout, F.A., Henry, H.R., Glover, R.E., 1964. Sea water in coastal aquifers. US Government Printing Office.

Custodio, E., 2002. Coastal aquifers as important natural hydrogeological structures. Groundwater and Human Development, Bocanegra et al (Eds).

Dahlin, T., 2001. The development of DC resistivity imaging techniques. Computers \&amp; Geosciences 27, 1019-1029.

Evans, R.L., Law, L.K., St. Louis, B., Cheesman, S., 2000. Buried paleo-channels on the New Jersey continental margin: channel porosity structures from electromagnetic surveying. Marine Geology 170, 381-394.

Ezzy, T.R., Cox, M.E., O’Rourke, A.J., Huftile, G.J., 2006. Groundwater flow modelling within a coastal alluvial plain setting using a highresolution hydrofacies approach; Bells Creek plain, Australia. Hydrogeology Journal 14, 675-688.

Falgàs, E., Ledo, J., Benjumea, B., Queralt, P., Marcuello, A., Teixidó, T., Martí, A., 2011. Integrating Hydrogeological and Geophysical Methods for the Characterization of a Deltaic Aquifer System. Surveys in Geophysics 32, 857-873.

Godin, L., 1990. Impact de la Riziculture sur l'Hydrologie et la Qualité des Eaux en Camargue. Thèse, Université d'Avignon et des Pays de Vaucluse, p. 180 pp.

Goldman, M., Neubauer, F.M., 1994. Groundwater exploration using integrated geophysical techniques. Surveys in Geophysics 15, 331-361. Griolet, C., 1972. Carte Hydrogéologique d'Arles. Université de Montpellier, pp. Atlas Hydrogéologique du Languedoc-Roussillon.

Guerin, R., 2005. Borehole and surface-based hydrogeophysics. Hydrogeology Journal 13, 251-254.

Heurteaux, P., 1969. Recherches sur les rapports des eaux souterraines avec les eaux de surface (étangs, marais, rizières), les sols halomorphes et la végétation en Camargue. Thèse, Université de Montpellier, p. 226 pp.

Holman, I.P., 2006. Climate change impacts on groundwater recharge- uncertainty, shortcomings, and the way forward? Hydrogeology Journal 14, 637-647.

Iribar, V., Carrera, J., Custodio, E., Medina, A., 1997. Inverse modelling of seawater intrusion in the Llobregat delta deep aquifer. Journal of Hydrology 198, 226-244.

L'Homer, A., 1975. Notice explicative de la carte géologique des Saintes-Mariés-de-la-mer au 1/50000, Feuille 1018. BRGM, Orléans, p. 34 pp.

L'Homer, A., Bazile, F., Thommeret, J., Thommeret, Y., 1981. Principales étapes de l'édification du delta du Rhône de 7000 BP à nos jours; variations du niveau marin. Oceanis 7, 389-408.

Lyons, R.P., Scholz, C.A., Buoniconti, M.R., Martin, M.R., 2011. Late Quaternary stratigraphic analysis of the Lake Malawi Rift, East Africa: An integration of drill-core and seismic-reflection data. Palaeogeography, Palaeoclimatology, Palaeoecology 303, 20-37.

Maillet, G.M., Rizzo, E., Revil, A., Vella, C., 2005. High Resolution Electrical Resistivity Tomography (ERT) in a Transition Zone Environment: Application for Detailed Internal Architecture and Infilling Processes Study of a Rhône River Paleo-channel. Marine Geophysical Research 26, 317-328.

Marescot, L., 2006. Introduction à l'imagerie électrique du sous-sol. Bull Vaudois Des Sci Nat 90, 23-40.

Marinos, P., 1969. Etudes hydrogéologiques en Camargue (volume II). Thèse de Doctorat, Université de Grenoble, Grenoble, p. 139 pp.

Martínez, J., Benavente, J., García-Aróstegui, J.L., Hidalgo, M.C., Rey, J., 2009. Contribution of electrical resistivity tomography to the study of detrital aquifers affected by seawater intrusion-extrusion effects: The river Vélez delta (Vélez-Málaga, southern Spain). Engineering Geology 108, 161-168.

Matsui, T., Park, S.G., Park, M.K., Matsuura, S., 2000. Relationship between electrical resistivity and physical properties of rocks, GeoEng. Melbourne Convention Centre, Melbourne, Australia.

McNeill, J., 1980. Electromagnetic terrain conductivity measurement at low induction numbers. Geonics Limited Mississauga, Ontario, Canada.

Monteiro Santos, F.A., 2004. 1-D laterally constrained inversion of EM34 profiling data. Journal of Applied Geophysics 56, 123-134.

Nobes, D.C., 1996. Troubled waters: Environmental applications of electrical and electromagnetic methods. Surveys in Geophysics 17, 393454 .

Parasnis, D.S., 1986. Principles of applied geophysics, Fourth Edition ed. Chapman and Hall Editions, London, New York.

Pham, V.N., Boyer, D., Le Mouël, J.-L., Kim Thoa Nguyen, T., 2002. Hydrogeological investigation in the Mekong Delta around Ho-ChiMinh City (South Vietnam) by electric tomography. Comptes Rendus Geoscience 334, 733-740.

Pons, A., Toni, C., Triat, H., 1979. Edification de la Camargue et histoire holocène de sa végétation. Terre et Vie, Revues Ecologiques 2, $13-$ 30 .

Sandberg, S.K., Slater, L.D., Versteeg, R., 2002. An integrated geophysical investigation of the hydrogeology of an anisotropic unconfined aquifer. Journal of Hydrology 267, 227-243.

Seaton, W.J., Burbey, T.J., 2002. Evaluation of two-dimensional resistivity methods in a fractured crystalline-rock terrane. Journal of Applied Geophysics 51, 21-41.

Sherif, M., Kacimov, A., Javadi, A., Ebraheem, A., 2012. Modeling Groundwater Flow and Seawater Intrusion in the Coastal Aquifer of Wadi Ham, UAE. Water Resources Management 26, 751-774.

Sirhan, A., Hamidi, M.O., 2012. Characterization by electrical and electromagnetic geophysical methods of the shallow hydrogeological system at Hebron (West Bank, Palestine) in a semi-arid zone. Comptes Rendus Geoscience 344, 449-460.

Skinner, D., Heinson, G., 2004. A comparison of electrical and electromagnetic methods for the detection of hydraulic pathways in a fractured rock aquifer, Clare Valley, South Australia. Hydrogeology Journal 12, 576-590.

Triantafilis, J., Odeh, I.O.A., Minasny, B., McBratney, A.B., 2003a. Elucidation of physiographic and hydrogeological features of the lower Namoi valley using fuzzy k-means classification of EM34 data. Environmental Modelling \&amp; Software 18, 667-680.

Triantafilis, J., Odeh, I.O.A., Minasny, B., McBratney, A.B., 2003b. Elucidation of physiographic and hydrogeological features of the lower Namoi valley using fuzzy k-means classification of EM34 data. Environmental Modelling \& Software 18, 667-680.

Vella, C., Fleury, T.-J., Raccasi, G., Provansal, M., Sabatier, F., Bourcier, M., 2005. Evolution of the Rhône delta plain in the Holocene. Marine Geology 222-223, 235-265.

Vouillamoz, J.M., Chatenoux, B., Mathieu, F., Baltassat, J.M., Legchenko, A., 2007. Efficiency of joint use of MRS and VES to characterize coastal aquifer in Myanmar. Journal of Applied Geophysics 61, 142-154.

Ward, S.H., Hohmann, G.W., 1988. Electromagnetic theory for geophysical applications. Electromagnetic methods in applied geophysics 1 , 131-311.

Zarroca, M., Bach, J., Linares, R., Pellicer, X.M., 2011. Electrical methods (VES and ERT) for identifying, mapping and monitoring different saline domains in a coastal plain region (Alt Empordà, Northern Spain). Journal of Hydrology 409, 407-422. 